Gut, 1986, 27, 382-385

\title{
Assessment of oxidative metabolism in adults with hepatocellular carcinoma in the Sudan
}

\author{
M M A HOMEIDA, T K DANESHMEND, ELMAHDI M ALI, \\ A $G$ M YOUSIF-ELKADARU, AND B M O ARBAB \\ University Department of Medicine, Khartoum, Sudan and the University Department of Medicine, Bristol \\ Royal Infirmary, Bristol
}

SUMmARY The hypothesis that an increased rate of oxidative metabolism may be an initiator or promoter of hepatocellular carcinoma was tested in vivo. Elimination of antipyrine (phenazone) was used as an index of the activity of microsomal mixed function oxidative enzymes. Plasma antipyrine kinetics were examined in 10 patients with hepatocellular carcinoma and in 10 normal Sudanese adults. The half life, volume of distribution and clearance of antipyrine in patients were $18 \cdot 8 \pm 7.9$ hours (mean $\pm \mathrm{SD}$ ), $33.8 \pm 7 \cdot 7$ litres and $23.7 \pm 10 \cdot 1 \mathrm{ml} / \mathrm{min}$, respectively; and in normal adults were $20 \cdot 3 \pm 8 \cdot 8$ hours, $40 \cdot 1 \pm 10.4$ litres and $25 \cdot 7 \pm 12.0 \mathrm{ml} / \mathrm{min}$, respectively. These differences were not significant. Antipyrine plasma clearance when corrected for weight was similar in the two groups. This study suggests that in a population at risk for hepatocellular carcinoma, the overall activity of mixed function oxidative enzymes is not an important determinant in selectively increasing this risk.

It is well recognised that microsomal mixed function oxidase enzymes are important in the biotransformation of xenobiotics into carcinogens. ${ }^{.}$In experimental animal models of liver cancer, potent inducers of mixed function oxidative enzymes, such as phenobarbitone and polychlorinated biphenols, act as promoters of carcinogenesis. ${ }^{2}$ We examined the rate of oxidative metabolism in vivo in African patients with hepatocellular carcinoma in the Sudan and in normal healthy subjects by measurement of antipyrine (phenazone) elimination. Antipyrine elimination rate in vivo has been shown to correlate with the activity of hepatic mixed function oxidative enzymes in vitro. ${ }^{3}$

\footnotetext{
Methods

PATIENTS

Ten patients with biopsy proven hepatocellular carcinoma, but without histological or clinical evidence of concurrent cirrhosis were selected for this study. The 10 normal subjects were matched for age and sex. Both groups were screened for but found not to have schistosomiasis, amoebiasis, and malaria. Serum was taken and frozen at $-20^{\circ} \mathrm{C}$ for

Address for correspondence: Dr T K Daneshmend. University Department of Medicine, Bristol Royal Infirmary. Bristol BS2 XHW. Avon.

Received for publication 19 July 1985
}

determination of liver function tests (bilirubin, alkaline phosphatase, aspartate aminotransferase, albumin, and globulin), serum alpha fetoprotein, and hepatitis B virus markers.

Each subject received antipyrine $1200 \mathrm{mg}$ as a freshly prepared solution after an overnight fast. No food was allowed for three hours after the dose. Venous blood samples were collected at three, six, nine, 12 , and 24 hours after the dose. Plasma was separated by centrifugation and stored frozen at $-20^{\circ} \mathrm{C}$. Serum and plasma samples were transported frozen to Bristol, England for analysis.

Liver function tests were measured by automated methods. Serum alpha fetoprotein was measured by radioimmunoassay ('GammaDab' $\left[{ }^{125} \mathrm{I}\right]$ AlphaFetoprotein, Clinical Assays, Travenol Laboratories). Hepatitis B virus markers were tested by radioimmunoassay for hepatitis $B$ surface antigen, hepatitis B core antibody and hepatitis B surface antibody.

Antipyrine was determined in plasma by a spectrophotometric method. ${ }^{4}$ The coefficient of variation of this assay was less than 5\%. Antipyrine half life $\left(t^{1 / 2}\right)$ was calculated by least squares regression analysis of log plasma concentration with respect to time. The apparent volume of distribution (V) of antipyrine was calculated as:

$$
\mathrm{V}=\mathrm{Dose} / \mathrm{C} \mathrm{p}_{\mathrm{o}}
$$


where $\mathrm{Cp}_{\mathrm{o}}$ is the back extrapolated plasma concentration of antipyrine at time zero and dose, the dose of antipyrine given. This calculation assumes complete absorption after oral administration, negligible presystemic elimination and a one compartment pharmacokinetic model for antipyrine. ${ }^{5}$ Antipyrine clearance $(\mathrm{CL})$ was calculated from:

$$
\mathrm{CL}=\mathrm{V}\left(0 \cdot 693 / \mathrm{t}^{1 / 2}\right)
$$

Statistical comparisons were made using Student's $t$ test for unpaired data, assuming unequal variance.

\section{Results}

The results of antipyrine kinetics in patients and normals are given in the Table. Mean values for antipyrine $t^{1} 1 / 2, \mathrm{~V}$ and $\mathrm{CL}$ were $7 \%, 16 \%$, and $8 \%$, respectively, lower in patients compared with normal subjects. These differences did not achieve statistical significance (Table). Correction of anti- pyrine clearance for weight increased the similarity between the two groups: $29.5 \pm 12.9$ (mean \pm SD) $\mathrm{ml} / \mathrm{h} / \mathrm{kg}$ in patients and $28.7 \pm 11.6$ in normal subjects. There was no correlation between serum albumin and antipyrine clearance $(r=0 \cdot 145$, $\mathrm{p}=0.54$ ), antipyrine clearance corrected for body weight $(r=0.062, p=0.80)$, antipyrine half life $(r=0.038, p=0.87)$ or antipyrine volume of distribution $(\mathrm{r}=0 \cdot 349, \mathrm{p}=0 \cdot 13)$.

The weight, serum bilirubin and serum globulin were similar in the two groups. Patients had significantly higher serum alkaline phosphatase (patients $43 \cdot 9 \pm 40 \cdot 7$, normal subjects $7 \cdot 7 \pm 7 \cdot 2$ KingArmstrong units) and aspartate aminotransferase (patients $34 \cdot 8 \pm 35 \cdot 6$, normal subjects $10 \cdot 3 \pm 7 \cdot 1 \mathrm{IU} / \mathrm{l}$ ). The serum albumin was $29.9 \pm 7.4 \mathrm{~g} / \mathrm{l}$ in patients and $43.9 \pm 4.6 \mathrm{~g} / \mathrm{l}$ in normal subjects. Six patients with hepatocellular carcinoma had a serum albumin value less than $35 \mathrm{~g} / \mathrm{l}$. All normal subjects had serum albumin values in the normal range.

Two patients only had raised alpha fetoprotein

Table Liver function tests and antipyrine kinetic parameters in 10 adults with hepatocellular carcinoma and 10 normal Sudanese adults

\begin{tabular}{|c|c|c|c|c|c|c|}
\hline \multirow[b]{2}{*}{ Patients } & \multirow[b]{2}{*}{$\begin{array}{l}\text { Sex/Age } \\
(y r s)\end{array}$} & \multirow[b]{2}{*}{$\begin{array}{l}\text { Weight } \\
\text { (kg) }\end{array}$} & \multicolumn{2}{|c|}{ Antipyrine kinetic values } & \multirow[b]{2}{*}{$\begin{array}{l}C L \\
m l / \text { min }\end{array}$} & \multirow[b]{2}{*}{$\begin{array}{l}C L / W t \\
m l / h / k g\end{array}$} \\
\hline & & & $\begin{array}{l}t^{t / 2} \\
h\end{array}$ & $\begin{array}{l}V D \\
\text { litres }\end{array}$ & & \\
\hline 1 & M 34 & $54 \cdot 2$ & $31 \cdot 1$ & $37 \cdot 2$ & $13 \cdot 8$ & $15 \cdot 3$ \\
\hline 2 & M 40 & $48 \cdot 7$ & $15 \cdot 1$ & $28 \cdot 1$ & $21 \cdot 5$ & $26 \cdot 5$ \\
\hline 3 & F 39 & $44 \cdot 1$ & $20 \cdot 1$ & $35 \cdot 3$ & $20 \cdot 3$ & $27 \cdot 6$ \\
\hline 4 & M 51 & $53 \cdot 6$ & 18.7 & $26 \cdot 4$ & $16 \cdot 4$ & $18 \cdot 2$ \\
\hline 5 & F 48 & $79 \cdot 0$ & $12 \cdot 0$ & $44 \cdot 0$ & $42 \cdot 5$ & $32 \cdot 3$ \\
\hline 6 & M 34 & $49 \cdot 1$ & $27 \cdot 4$ & $35 \cdot 0$ & $14 \cdot 7$ & $18 \cdot 0$ \\
\hline 7 & M 42 & $41 \cdot 2$ & $9 \cdot 7$ & $27 \cdot 9$ & $33 \cdot 1$ & $48 \cdot 2$ \\
\hline 8 & F 58 & $34 \cdot 3$ & $9 \cdot 8$ & $22 \cdot 8$ & $26 \cdot 8$ & 46.9 \\
\hline 9 & F 36 & $48 \cdot 0$ & $28 \cdot 6$ & $34 \cdot 4$ & 13.9 & $17 \cdot 4$ \\
\hline 10 & M 49 & $46 \cdot 7$ & $15 \cdot 7$ & $47 \cdot 0$ & $34 \cdot 5$ & $44 \cdot 3$ \\
\hline Mean & & 49.9 & $18 \cdot 8$ & $33 \cdot 8$ & $23 \cdot 7$ & $29 \cdot 5$ \\
\hline SD & & $11 \cdot 8$ & 7.9 & $7 \cdot 7$ & $10 \cdot 1$ & $12 \cdot 9$ \\
\hline \multicolumn{7}{|c|}{ Normal subjects } \\
\hline 1 & M 29 & $54 \cdot 0$ & $18 \cdot 6$ & $53 \cdot 3$ & $33 \cdot 1$ & $36 \cdot 8$ \\
\hline 2 & M 37 & $52 \cdot 2$ & $23 \cdot 7$ & $43 \cdot 2$ & $21 \cdot 1$ & $24 \cdot 2$ \\
\hline 3 & F 34 & $49 \cdot 6$ & $14 \cdot 3$ & $27 \cdot 0$ & $21 \cdot 6$ & $26 \cdot 1$ \\
\hline 4 & F 28 & $50 \cdot()$ & $17 \cdot 1$ & $36 \cdot 3$ & $24 \cdot 6$ & $29 \cdot 5$ \\
\hline 5 & F 43 & $51 \cdot 1$ & $23 \cdot 3$ & $26 \cdot 4$ & $13 \cdot 1$ & $15 \cdot 4$ \\
\hline 6 & F 31 & $45 \cdot 0$ & $19 \cdot 4$ & $31 \cdot 3$ & $18 \cdot 7$ & $24 \cdot 9$ \\
\hline 7 & M 44 & $55 \cdot 4$ & $16 \cdot 4$ & $43 \cdot 7$ & $31 \cdot 0$ & $33 \cdot 6$ \\
\hline 8 & M 26 & $55 \cdot 0$ & $43 \cdot 1$ & $45 \cdot 3$ & $12 \cdot 1$ & $13 \cdot 2$ \\
\hline 9 & M 30) & $58 \cdot 6$ & $15 \cdot 0$ & $37 \cdot 3$ & 28.6 & $29 \cdot 3$ \\
\hline 10 & M 33 & $59 \cdot 0$ & $12 \cdot 3$ & $57 \cdot 1$ & $53 \cdot 4$ & $54 \cdot 3$ \\
\hline Mean & & $53 \cdot 0$ & $20 \cdot 3$ & $4(0) \cdot 1$ & $25 \cdot 7$ & 28.7 \\
\hline SD & & $4 \cdot 3$ & $8 \cdot 8$ & $10 \cdot 4$ & $12 \cdot()$ & $11 \cdot 6$ \\
\hline \multicolumn{7}{|c|}{ Significance* } \\
\hline ( $p$ value) & & 0.45 & 0.69 & 0.14 & 0.69 & 0.89 \\
\hline
\end{tabular}

$\mathrm{t}^{1 / 2}=$ plasma antipyrine half life: $\mathrm{VD}=$ volume of distribution of antipyrinc; $\mathrm{CL}=$ plasma antipyrine clearance: $\mathrm{CL} / \mathrm{Wt}=\mathrm{plasma} \mathrm{clearance}$ of antipyrine corrected for body weight. ${ }^{*}$ Student's $t$ test for unpaired data, assuming unequal variance, comparing normal subjects and patients. 
concentrations greater than $4000 \mathrm{IU} / \mathrm{ml}$. The remainder of patients and controls had undetectable or low concentrations of alpha fetoprotein. Evidence of past or present hepatitis B virus infection was found in nine patients and three normal subjects.

\section{Discussion}

In three British patients with hepatocellular carcinoma but not cirrhosis, we have previously noted a $51 \%$ lower antipyrine clearance; mean $17.7 \mathrm{ml} / \mathrm{min}$ in patients, mean $36.5 \mathrm{ml} / \mathrm{min}$ in normal subjects. ${ }^{6}$ In six Finnish patients with hepatocellular carcinoma but not cirrhosis, the mean antipyrine clearance was $40 \cdot 1 \mathrm{ml} / \mathrm{min}$, a figure no different to that in normal subjects. ${ }^{7}$ In contrast, three Finnish patients with hepatoma and coexistant cirrhosis had markedly reduced antipyrine clearance with a mean of $12.1 \mathrm{ml} / \mathrm{min}^{7}$

In the present study the mean antipyrine clearance of $23.7 \mathrm{ml} / \mathrm{min}$ in Sudanese patients with hepatocellular carcinoma was intermediate between the results obtained in Finland and England. This value would be significantly lower if Sudanese patients were compared with antipyrine clearance values of control subjects in the other two studies. In the present study, however, we allowed for environmental and racial differences in the rate of antipyrine elimination ${ }^{8}$ by comparing patients with Sudanese normal subjects. The mean antipyrine clearance in normal subjects in the present study $(25.7 \mathrm{ml} / \mathrm{min})$ is similar to that noted previously in eleven other normal subjects in the Sudan $(27.2 \mathrm{ml} / \mathrm{min}){ }^{9}$

In the Finnish study, a correlation was observed between antipyrine elimination and the amount of tumour free liver parenchyma in hepatocellular carcinoma patients, but not in patients with metastatic liver cancer. ${ }^{7}$ While we did not quantify the extent of liver tissue replaced by tumour in the present study, such a relationship seems likely because the activity of mixed function oxidative enzymes is reduced within hepatocellular carcinoma tissue. ${ }^{10}$ In the present study we observed no relationship between antipyrine kinetic parameters and the serum albumin concentration, an index of liver synthetic function which correlates well with antipyrine elimination in chronic parenchymal liver disease. ${ }^{6}$ In our previous study, ${ }^{6}$ British patients with hepatocellular carcinoma had a mean serum albumin of $36.3 \mathrm{~g} / \mathrm{l}$, in contrast with $45.4 \mathrm{~g} / \mathrm{l}$ in normal subjects $(\mathrm{p}<0 \cdot 05)$.

At presentation, hepatocellular carcinoma patients in Britain often have a reduced serum albumin. Melia et al $^{11}$ found a low serum albumin in
$40 \%$ of hepatocellular carcinoma patients without cirrhosis and in $73 \%$ with cirrhosis. In the present study, $60 \%$ of Sudanese patients without cirrhosis had a low serum albumin. This higher figure may be related to the somewhat later presentation of Sudanese patients. In view of our previous findings, the lack of correlation between antipyrine clearance and serum albumin is somewhat surprising. Detailed examination of the data did not reveal any factor to account for this apparent discrepant result. It should be recalled, however, that the relationship between antipyrine clearance and serum albumin was found in a hetergeneous group of 29 patients with liver disease of varying aetiology, of whom only three had hepatoma. ${ }^{6}$ Assuming serum albumin concentration to represent hepatic synthetic function, the present study suggests that this may be compromised earlier than hepatic oxidative activity in hepatocellular carcinoma without cirrhosis. Sequential withinpatient studies may help resolve this issue.

Hepatic carcinogenesis is a multistep process and the sequence of neoplastic transformation includes initiation, promotion, differential inhibition and differential stimulation. ${ }^{12}$ The majority of carcinogens - for example, nitrosamines, aromatic amines, and aflatoxins, require metabolic activation, predominantly by hepatocyte mixed function oxidative enzymes. The reactions of mixed function oxidative enzymes, catalysed by the haemoprotein cytochrome P-450, are under the influence of genetic and environmental factors. ${ }^{13}$ An increase in hepatocellular carcinoma among cigarette smokers, independent of alcohol intake, has been found in Greece and Hong Kong. ${ }^{14}$ Cigarette smoking is a known inducer of mixed function oxidative enzymes, in addition to producing carcinogens. In hepatocellular carcinoma the activity of mixed function oxidative enzymes is increased in liver tissue adjacent to the tumour, ${ }^{15}$ but reduced within it. ${ }^{10}$ In developed countries, alcohol is a risk factor for hepatocellular carcinoma ${ }^{14} 16$ and its chronic intake results in increased mixed function oxidative enzyme activity. Hepatocellular carcinoma, however, more commonly arises in developed countries in livers with cirrhosis, ${ }^{611}$ a condition associated with reduced mixed function oxidative activity. Contamination of food by aflatoxins has a high geographical association with the incidence of hepatocellular carcinoma. ${ }^{14}$ Aflatoxin accumulation in the liver may occur in childhood during protein calorie malnutrition as a consequence of impaired mixed function oxidative activity. ${ }^{17}$ An increase in mixed function oxidative activity during dietary rehabilitation may cause stored aflatoxin to be converted to carcinogens. This process occurring during childhood against a background of rapid liver 
regeneration may initiate and promote hepatocellular carcinoma. ${ }^{17}$ Nevertheless, the link between carcinogenesis and activity of mixed function oxidative enzymes is far from clear in man. ${ }^{18}$

The present study shows that there is no major difference in overall oxidative metabolism in patients with hepatocellular carcinoma when compared with normal adults in the Sudan. It is evident, however, that this study measured oxidative metabolism after diagnosis of hepatocellular carcinoma. Thus the absence of such a difference at the time of diagnosis does not exclude the possibility of increased mixed function oxidative enzyme activity before presentation which may have resulted in carcinogen production and led to the development of hepatocellular carcinoma. As a consequence, repeated observations of mixed function oxidative activity in a representative sample of a population with a high incidence of hepatocellular carcinoma may be necessary. It is possible that more subtle differences in oxidative metabolism exist than can be ascertained by antipyrine elimination. Recognition of the multiplicity of cytochrome P-450 dependent mixed function oxidative iosenzymes ${ }^{13}$ suggests that determination of specific polymorphisms in human drug metabolism ${ }^{19}$ in a population at risk may unravel the contribution of genetic and environmental influences on hepatic carcinogenesis.

We thank Miss Julia Ford, Senior Technician, University Department of Medicine, Bristol Royal Infirmary for her technical assistance and Dr E M Vandervelde, Senior Medical Microbiologist, Virus Reference Laboratory, Colindale, London for carrying out the hepatitis B virus serology.

\section{References}

1 Alvares AP. Oxidative biotransformation of drugs. In: Arias I, Popper H, Schachter D, Shafritz DS, eds. The Liver: biology and pathobiology New York: Raven Press, 1982: 265-80.

2 Nishimizumi $M$. Enhancement of diethylnitrosamine hepatocarcinogenesis in rats exposed to polychlorinated biphenyls or phenobarbital. Cancer Lett 1976; 2: 11-6.

3 Vuitton D, Miguet JP, Camelot G et al. Relationship between metabolic clearance rate of antipyrine and hepatic microsomal drug-oxidizing enzyme activities in humans without liver disease. Gastroenterology 1981; 80: $112-8$.
4 Brodie BB, Axelrod J, Soberman R, Levy BB. The estimation of antipyrine in biological materials. $J$ Biol Chem 1949; 179: 25-9.

5 Andreasen PB, Vesell ES. Comparison of plasma levels of antipyrine, tolbutamide and warfarin after oral and intravenous administration. Clin Pharm Ther 1974; 4: $129-34$.

6 Homeida M, Roberts CJC, Halliwell M, Read AE, Branch RA. Antipyrine clearance per unit volume liver: an assessment of hepatic function in chronic liver disease. Gut 1979; 20: 596-601.

7 Sotaniemi EA, Pelkonen RO, Mokka RE, Huttunen $\mathrm{R}$, Viljakainen $\mathrm{E}$. Impairment of drug metabolism in patients with liver cancer. Eur J Clin Invest 1977; 7: 269-74.

8 Homeida M. Hepatic drug metabolism. University of Bristol: MD Thesis, 1978.

9 Homeida M, Salih SY, Branch RA. Drug metabolism in hepatosplenic schistosomiasis in the Sudan: a study with antipyrine. Gut 1978; 98: 808-11.

10 Sultatos LG, Vesell ES. Enhanced drug-metabolizing capacity within liver adjacent to human and rat liver tumors. Proc Natl Acad Sci USA 1980; 77: 600-3.

11 Melia WM, Wilkinson ML, Portmann BC, Johnson PJ, Williams R. Hepatocellular carcinoma in the noncirrhotic liver: a comparison with that complicating cirrhosis. $Q J$ Med 1984; 53 (New series): 391-400.

12 Farber E. Neoplastic Transformation. In: Arias I, Popper H, Schachter D, Shafritz DS. eds. The Liver: biology and pathobiology. New York: Raven Press, 1982: 881-9.

13 Meyer UA. The clinical pharmacology of cytochrome P-450. In: Lemberger L, Reidenberg MM, eds. Proceedings of the second world conference on clinical pharmacology and therapeutics. Bethesda: American Society for Pharmacology and Experimental Therapeutics, 1984: 331-41.

14 Cook-Mozaffari P, Van Rensburg S. Cancer of the liver. Br Med Bull 1984; 40: 342-5.

15 Sultatos LG, Liu DK, Vesell ES. Further studies on the increase in drug-metabolizing capacity adjacent to intrahepatic Morris hepatomas. Biochem Pharmacol 1981; 30: 971-8.

16 Popper H, Mori W. Summary of United States-Japan Cooperative Seminar on Human Hepatocarcinogenesis, January 20-22, 1983, Honolulu, Hawaii. J Natl Cancer Inst 1983; 71: 1095-9.

17 Enwonwu CO. The role of dietary aflatoxin in the genesis of hepatocellular cancer in developing countries. Lancet 1984; 2: 956-8.

18 Gelboin HV. Carcinogens, drugs and cytochromes P450. $N$ Engl J Med 1983; 309: 105-7.

19 Idle JR, Smith RL. The debrisoquine hydroxylation gene: a gene of multiple consequence. In: Lemberger $\mathrm{L}$, Reidenberg MM. Proceedings of the second world conference of clinical pharmacology and therapeutics. Bethesda: American Society for Pharmacology and Experimental Therapeutics. 1984: 148-64. 